Suherman, C. • A. Nuraini $\cdot$ V.S.R. Wulandari

\title{
Respons tiga klon tanaman rami (Boehmeria nivea (L.) Gaud) terhadap konsentrasi asam giberelat yang berbeda
}

\author{
Response of three clones of ramie (Boehmeria nivea L. Gaud) under \\ different giberellic acid concentrations treatment
}

Diterima : 11 Desember 2017/Disetujui : 18 Desember 2017 / Dipublikasikan : 30 Desember 2017

(CDepartment of Crop Science, Padjadjaran University

\begin{abstract}
Ramie is one of the fiber-producing crops that can be used for textile industry. The objective of this study was to study the effect of the interaction between several clones of ramie and Giberellic Acid $\left(\mathrm{GA}_{3}\right)$ concentration on the growth and yield of ramie. The experiment was conducted at Ciparanje Experimental field, Faculty of Agriculture, Universitas Padjadjaran, Sumedang Regency from February 2017 to April 2017. The type of rainfall of the experimental area is classified as type $\mathrm{C}$ according to Schmidt and Fergusson's with altitude of $754 \mathrm{~m}$ above the sea level and ordo of soil in the field is Inceptisol. The experiment was arranged in factorial randomized block design with two factors and three replications. First factor was clone of ramie, consisted of three levels, Pujon 13, Bandung A, and Ramindo 1. Second factor was giberellic acid concentrations, consisted of four levels, 0 ppm, 75 ppm, 150 ppm, and 225 ppm. The experimental results showed that there was an effect of clonal interaction with GA3 concentration on the number of leaves aged week after planting (WAP), stem diameter aged 8 and $12 \mathrm{WAP}$, and plant height $12 \mathrm{WAP}$. The best interaction effect occurred in Bandung A clone treatment with $225 \mathrm{ppm}$ gibberellic acid. It was indicated by leaf number of $12 \mathrm{WAP}$, and stem diameter of 8 and 12 WAP. The best independent effect was displayed at Bandung A clone and 225 ppm of gibberellic acid.
\end{abstract}

Keywords: Giberellic Acid, Clone, Ramie

\footnotetext{
Dikomunikasikan oleh Agus Wahyudin

Suherman, C. ${ }^{1} \cdot$ A. Nuraini ${ }^{1}$ · V.S.R. Wulandari ${ }^{2}$

${ }^{1}$ Dosen Departemen Budidaya Pertanian Fakultas

Pertanian UNPAD

${ }^{2}$ Alumni Departemen Budidaya Pertanian Fakultas

Pertanian UNPAD

Korespondensi : cucu.sv@unpad.ac.id
}

Sari Tanaman rami merupakan salah satu jenis tanaman perkebunan penghasil serat yang seratnya dapat dimanfaatkan dalam industri tekstil. Penelitian ini bertujuan untuk mengetahui pengaruh interaksi zat pengatur tumbuh asam giberelat (GA3) dan tiga klon rami terhadap pertumbuhan dan hasil tanaman rami serta mengetahui interaksi konsentrasi asam giberelat dan klon rami yang paling baik. Percobaan dilakukan di Kebun Percobaan Ciparanje, Fakultas Pertanian, Universitas Padjadjaran, Kabupaten Sumedang, ordo tanah Inceptisol, waktu pelaksanaan bulan Februari 2017 sampai bulan April 2017. Tipe curah hujan C (agak basah) menurut klasifikasi Schmidt dan Fergusson, dengan ketinggian tempat $754 \mathrm{mdpl}$. Percobaan ini menggunakan Rancangan Acak Kelompok pola Faktorial dengan dua belas perlakuan dan tiga ulangan. Faktor pertama adalah klon rami yang terdiri atas tiga taraf, yaitu Pujon 13, Bandung A, dan Ramindo 1. Faktor kedua adalah konsentrasi asam giberelat, yaitu 0 ppm, 75 ppm, 150 ppm, dan $225 \mathrm{ppm}$. Hasil percobaan menunjukkan terdapat pengaruh interaksi klon dengan konsentrasi $\mathrm{GA}_{3}$ terhadap jumlah daun umur 12 MST, diameter batang umur 8 dan 12 MST, dan tinggi tanaman 12 MST. Pengaruh interaksi terbaik terjadi pada perlakuan klon Bandung A dengan asam giberelat 225 ppm, ditunjukkan oleh jumlah daun umur 12 MST, serta diameter batang umur 8 dan 12 MST. Pengaruh mandiri terbaik juga dihasilkan oleh klon Bandung A serta asam giberelat 225 ppm.

Kata kunci: Asam Giberelat, Klon, Rami

\section{Pendahuluan}

Tanaman rami merupakan salah satu jenis tanaman perkebunan semusim yang diambil seratnya. Serat pada tanaman rami terdapat 
pada batangnya, terutama pada kulit batang. Serat pada tanaman rami ini juga dapat digunakan sebagai bahan baku pengganti kapas sehingga dapat menambah pasokan serat alam. Tanaman rami memiliki potensi yang cukup tinggi dimana seratnya dapat diolah menjadi kain berkualitas tinggi. Serat rami juga merupakan bahan untuk pembuatan selulosa dengan kualitas yang cukup tinggi. Selain seratnya, bagian lain dari tanaman rami juga dapat dimanfaatkan untuk memenuhi kebutuhan sehari-hari seperti kebutuhan sandang. Bagian lain tanaman rami tersebut yaitu bagian daun (dapat dimanfaatkan sebagai kompos dan pakan ternak yang bergizi tinggi) dan batang tanaman rami (baik digunakan sebagai kayu bakar) (Purwati, 2010).

Menurut Sumantri (1989) dalam Trisiana dkk. (2016), serat rami juga memiliki kekuatan yang lebih baik dari serat kapas diantaranya memiliki kekuatan empat kali lebih besar dari serat kapas dan produktivitas rami juga lebih tinggi.Rami dapat dipanen lebih dari satu kali dalam setahun dan apabila dibandingkan dengan kapas, produktivitas rami:kapas yaitu 6:1. Serat rami memiliki beberapa keunggulan dibandingkan serat kapas. Tanaman rami sendiri memiliki produktivitas yang lebih baik dari serat kapas dimana serat rami dapat dipanen berkali-kali dalam satu tahun. Serat rami juga memiliki banyak keunggulan dari serat kapas diantaranya memiliki daya serap air yang lebih baik serta memiliki warna dan kilau serat yang hampir sama dengan sutera alam (Mudyantini, 2008)

Adanya kenyataan bahwa kebutuhan akan serat alam yang tinggi maka diperlukan upaya meningkatkan produksi pada tanaman rami, diantaranya dapat dilakukan dengan pemilihan klon unggul dan penambahan zat pengatur tumbuh pada tanaman rami. Tidak semua klon tanaman rami memiliki produktivitas yang baik dan dapat menggantikan kebutuhan bahan baku kapas dengan baik. Terdapat beberapa klon tanaman rami yang memiliki sifat yang unggul diantaranya klon Pujon 10 atau yang lebih dikenal dengan klon Ramindo I, Pujon 13, dan Bandung A. Ketiga klon tanaman rami tersebut memiliki daya adaptasi yang luas pada berbagai ketinggian tempat tanam dibandingkan dengan klon tanaman rami yang lainnya. Selain itu, produktivitas ketiga klon tersebut termasuk kategori sangat tinggi yaitu berkisar antara 2,02,7 ton/ha/tahun untuk klon Ramindo I, 1,9-2,5 ton/ha/tahun untuk klon Pujon 13, dan 2-2,5 ton/ha/tahun untuk klon Bandung A (Musaddad, 2007).

Produktivitas rami juga dapat ditingkatkan dengan penambahan zat pengatur tumbuh. Zat pengatur tumbuh merupakan senyawa organik yang apabila berada dalam konsentrasi yang rendah dapat mendorong, menghambat, dan dapat mengubah pertumbuhan dan perkembangan tanaman secara kualitatif. Salah satu senyawa yang sering digunakan untuk merekayasa pertumbuhan tanaman yaitu hormon giberelin (khususnya $\mathrm{GA}_{3}$ atau asam giberelat). Cara mengaplikasikan asam giberelat ini dapat dengan berbagai cara, diantaranyayaitu dengan disemprotkan langsung ke tanaman atau dengan merendam benih pada larutan asam giberelat.

Senyawa $\mathrm{GA}_{3}$ dapat memacu pertumbuhan tanaman dan meningkatkan ukuran pada berbagai organ tanaman seperti pada daun, bunga, dan buah. Meningkatnya ukuran tanaman karena pengaplikasian $\mathrm{GA}_{3}$ disebabkan karena adanya pembelahan dan pembesaran sel. Asam giberelat juga akan meningkatkan jumlah floem pada tanaman (Mudyantini, 2008). Seiring terjadinya peningkatan jumlah floem ini, maka jumlah selulosa dan lignin penyusun dinding sel juga akan meningkat dimana selulosa dan lignin ini merupakan faktor penentu kualitas dari serat rami (Mudyantini, 2008). Senyawa $\mathrm{GA}_{3}$ yang diaplikasikan pada tanaman mentimun akan berinteraksi dengan varietas tanaman tersebut memengaruhi pertumbuhan tanaman seperti tinggi tanaman dan jumlah batang (Depari, 2013).

Asam giberelat $\left(\mathrm{GA}_{3}\right)$ yang diberikan pada tanaman yang berbeda akan menunjukkan respons yang berbeda tergantung varietas dan faktor genetiknya (Budiarto dan Wuryaningsih, 2007). Tanaman rami yang diaplikasikan zat pengatur tumbuh $\mathrm{GA}_{3}$ juga akan menunjukkan respons yang berbeda setiap klonnya, dipengaruhi faktor genetik tanaman itu sendiri. Menurut Mudyantini (2008), pemberian $\mathrm{GA}_{3}$ sebanyak 200 ppm pada tanaman rami meningkatkan kandungan lignin tanaman, tinggi batang tunas, diameter batang, bobot basah, bobot kering, panjang berkas floem, jumlah floem, dan jumlah tunas serta daun pada tanaman rami. Selain itu, pemberian $\mathrm{GA}_{3} 200$ ppm pada tanaman rami juga tidak meningkatkan kandungan selulosa pada tanaman rami. Pemberian $\mathrm{GA}_{3}$ sebanyak $250 \mathrm{ppm}$ pada tanaman rami akan mengurangi 
tinggi batang tunas, diameter batang tunas, dan bobot basah tanaman (Mudyantini, 2008).

Menurut Syafi'i (2005) pemberian asam giberelat dengan konsentrasi 120 ppm mampu meningkatkan tinggi pada tanaman melon (Cucumis melo L.) sedangkan pada konsentrasi 60 ppm meningkatkan berat berangkasan segar tanaman, berat berangkasan kering tanaman, berat buah, diameter buah, dan tebal daging buah.Percobaan yang dilakukan oleh Suherman dkk. (2017) memberikan hasil dimana kombinasi antara pupuk organik cair $40 \mathrm{~mL} / \mathrm{L}$ dan $\mathrm{GA}_{3} 150$ ppm yang diaplikasikan kepada tanaman rami klon Pujon 13 mampu meningkatkan tinggi tanaman. Kombinasi yang sama tidak berbeda nyata pada seluruh perlakuan dengan parameter diameter batang, bobot segar batang, dan bobot kering tanaman.

Penggunaan klon unggul juga perlu diperhatikan dimana klon unggul ini juga akan mendukung pertumbuhan, kualitas, dan hasil serat rami yang terbentuk. Klon unggul rami yang digunakan dalam penelitian ini yaitu klon Ramindo 1, Pujon 13, dan Bandung A. Klon Ramindo 1 merupakan klon rami yang memiliki produktivitas 2 sampai dengan 2,7 ton/ha/ tahun dengan daya adaptasi pada ketinggian tempat yang luas. Klon Pujon 13 merupakan klon unggul rami yang memiliki produktivitas 1,9 sampai dengan 2,5 ton/ha/tahun dengan adaptasi ketinggian tempat yang luas. Rami dengan klon Bandung A merupakan klon unggul rami yang memiliki produktivitas 2 sampai dengan 2,6 ton/ha/tahun dengan daya adaptasi ketinggian tempat yang luas (Musaddad, 2007). Daya adaptasi ketinggian tempat yang luas pada ketiga klon tanaman rami ini menunjukkan bahwa tanaman rami dengan klon tersebut dapat tumbuh di berbagai ketinggian tempat yaitu rendah, medium, tinggi.

Percobaan ini menggunakan tiga klon tanaman rami yang berbeda serta empat konsentrasi asam giberelat $\left(\mathrm{GA}_{3}\right)$ yang berbeda. Ketiga klon tanaman rami yang digunakan memiliki produktivitas yang berbeda-beda sehingga dari pengaplikasian $\mathrm{GA}_{3}$ pada percobaan ini diduga akan menghasilkan respons yang berbeda pula pada ketiga klon tanaman rami. Berdasarkan uraian di atas, perlakuan asam giberelat diharapkan mampu berinteraksi dengan berbagai klon rami dan memberikan hasil yang berbeda terhadap pertumbuhan dan hasil tanaman rami. Penelitian ini bertujuan untuk mengetahui konsentrasi asam giberelat yang paling baik untuk pertumbuhan tanaman rami pada ketiga klon tersebut (Ramindo 1, Pujon 13, dan Bandung A).

\section{Bahan dan Metode}

Percobaan dilakukan di Kebun Percobaan Ciparanje, Fakultas Pertanian, Universitas Padjadjaran, Kecamatan Jatinangor, Kabupaten Sumedang. Ketinggian tempat lahan Percobaan yaitu 754 mdpl dengan ordo tanah Inceptisol dan tipe iklim berdasarkan curah hujan termasuk ke dalam tipe iklim C menurut klasifikasi Schmidt dan Fergusson (1951). Percobaan dilakukan pada bulan Februari tahun 2017 sampai dengan bulan April tahun 2017.

Bahan-bahan yang digunakan dalam percobaan ini yaitu: tanaman rami klon Ramindo 1, Bandung A, dan Pujon 13 umur 1 tahun, diambil bagian rhizoma nya dan diratoonkan sepanjang $10 \mathrm{~cm}$, Tanah Inceptisol sebagai media tanam, Zat pengatur tumbuh asam giberelat $\left(\mathrm{GA}_{3}\right)$, Polibeg hitam berukuran $50 \times 50 \mathrm{~cm}$ sebanyak 72 buah untuk penanaman rhizoma rami.

Alat yang digunakan dalam percobaan yaitu alat tulis, label, pisau, alat penyiram (emrat), jangka sorong untuk mengukur diameter batang tanaman rami, alat ukur panjang berupa meteran, Hand sprayer, oven untuk mengeringkan tanaman rami yang didestruksi, dan timbangan analitik.

Percobaan menggunakan Rancangan Acak Kelompok (RAK) pola faktorial dan diulang sebanyak tiga kali. Faktor pertama adalah perlakuan klon (k) yang terdiri atas tiga taraf : $k_{1}$ : Pujon 13, $\mathrm{k}_{2}$ : Bandung A, $\mathrm{k}_{3}$ : klon Ramindo 1. Faktor kedua adalah perlakuan pemberian konsentrasi $\mathrm{GA}_{3}(\mathrm{~g})$ yang terdiri atas empat taraf : $\mathrm{g}_{1}$ : tanpa larutan $\mathrm{GA}_{3}$ (kontrol), $\mathrm{g}_{2}$ : konsentrasi $\mathrm{GA}_{3} 75$ ppm, $\mathrm{g}_{3}$ : konsentrasi GA 3150 ppm, $\mathrm{g}_{4}$ : konsentrasi $\mathrm{GA}_{3} 225 \mathrm{ppm}$.

Lahan yang digunakan untuk penanaman rami dibersihkan dari sampah, gulma, dan sisasisa tanaman. Jarak antar polibeg dalam satu satuan percobaan yaitu $50 \mathrm{~cm}$, dengan jarak antar perlakuan $70 \mathrm{~cm}$, dan jarak antar ulangan $80 \mathrm{~cm}$.

Bahan tanam tanaman rami didapat dari hasil penelitian sebelumnya dimana bahan tanam diratoonkan terlebih dahulu sebelum ditanam. Rhizoma tanaman rami dipotong terlebih dahulu sepanjang $10 \mathrm{~cm}$ baru kemudian ditanam. 
Percobaan menggunakan media tanam berupa campuran tanah dan pupuk kandang kambing. Tanah yang digunakan yaitutopsoil tanah Inceptisol Jatinangor, kemudian dicampur dengan pupuk kandang kambing. Media dimasukkan ke dalam polibeg ukuran $50 \mathrm{~cm} x$ $50 \mathrm{~cm}$. Setiap polibeg diletakkan sesuai dengan tata letak percobaan.

Pupuk yang digunakan terdiri atas pupuk organik kandang kambing dengan dosis 400 $\mathrm{g} /$ tanaman dan pupuk anorganikterdiri atas pupuk urea sebanyak 3,2 g/polybag, pupuk SP36 sebanyak 2,4 g/polybag, dan pupuk $\mathrm{KCl}$ sebanyak 6,7 g/polybag, diaplikasikan pada saat penanaman. $\mathrm{GA}_{3} y$ ang digunakan pada percobaan yaitu dengan merek dagang Progibb. $\mathrm{GA}_{3}$ diaplikasikan pada tanaman rami sesuai dengan perlakuan yang dicobakan yaitu dengan konsentrasi 0 ppm, 75 ppm, 150 ppm, dan 225 ppm. Cara pengaplikasiannya yaitu dengan menyemprotkan larutan $\mathrm{GA}_{3}$ pada tanaman rami dengan dosis sesuai hasil kalibrasi, pada minggu kedua, minggu keempat, dan minggu keenam.

Pemeliharaan tanaman rami yaitu dengan melakukan penyiangan gulma, penyiraman, dan pengendalian hama penyakit pada tanaman. Penyiangan gulma dilakukan dengan cara manual yaitu mencabut gulma yang tumbuh di polibeg.Pemanenan tanaman rami dilakukan dengan memotong batang utama tanaman rami sampai rata dengan tanah atau menyisakan $5 \mathrm{~cm}$ dari permukaan tanah. Kriteria panen untuk tanaman rami menurut Musaddad (2007), yaitu:warna kulit pangkal batang yang asalnya hijau telah berubah menjadi berwarna coklat, batang mudah untuk pecah, bagian tengah batang sulit untuk dipatahkan, terdapat tunastunas baru yang mulai tumbuh, laju pertumbuhannya berkurang.

Pengamatan meliputi: pertambahan jumlah anakan (buah) pada, 8, 10, dan 12 MST, pertambahan jumlah daun (buah), pertambahan diameter batang $(\mathrm{cm})$, bobot segar tanaman $(\mathrm{g})$ pada umur 12 MST, pertambahan tinggi tanaman $(\mathrm{cm}) 8$ MST, 10 MST, dan 12 MST.

\section{Hasil dan Pembahasan}

Pertambahan jumlah anakan. Pertambahan jumlah anakan pada 8, 10 dan 12 MST tidak dipengaruhi oleh interaksi klon dengan $\mathrm{GA}_{3}$, tetapi dipengaruhi secara mandiri oleh klon maupun konsentrasi GA $\mathrm{G}_{3}$ (Tabel 1)

Pertambahan jumlah anakan rami pada umur 8 MST dan 12 MST paling tinggi pada perlakuan Pujon 13 dibandingkan dengan perlakuan klon Bandung A dan Ramindo 1, tetapi pada umur 8 MST pertambahan jumlah anakanklon Pujon 13 tidak berbeda dengan Bandung A. Menurut deskripsi, jumlah anakan produktif rami klon Ramindo 1 lebih banyak dibandingkan dengan klon Pujon 13. Jumlah anakan yang muncul berkaitan erat dengan jumah mata tunas yang ada pada rhizoma. Menurut Mudyantini (2008) setiap potongan rhizoma pada rami dengan klon yang berbeda akan memiliki panjang ruas yang berbeda pula. Potongan rhizoma yang sama belum tentu menunjukkan jumlah mata tunas yang sama pada setiap klonnya, walaupun pada awal percobaan bahan tanam telah dianggap sama.

Pada 10 MST, perlakuan $\mathrm{GA}_{3} 225 \mathrm{ppm}$ menghasilkan pertambahan jumlah anakan yang lebih baik dibandingakan perlakuan lainnya tetapi tidak berbeda dengan perlakuan 150 ppm.

Tabel 1. Pengaruh Mandiri Klon Rami dan Konsentrasi Asam Giberelat terhadap Pertambahan Jumlah Anakan

\begin{tabular}{lccc}
\hline \multirow{2}{*}{ Perlakuan } & \multicolumn{3}{c}{ Pertambahan Jumlah Anakan (buah) } \\
\cline { 2 - 4 } & $8 \mathrm{MST}$ & $10 \mathrm{MST}$ & $12 \mathrm{MST}$ \\
\hline Klon (K) & $1,88 \mathrm{~b}$ & $1,54 \mathrm{a}$ & $3,58 \mathrm{~b}$ \\
$\mathrm{k}_{1}$ (Pujon 13) & $1,42 \mathrm{~b}$ & $1,75 \mathrm{a}$ & $1,46 \mathrm{a}$ \\
$\mathrm{k}_{2}$ (Bandung A) & $0,58 \mathrm{a}$ & $1,00 \mathrm{a}$ & $1,67 \mathrm{a}$ \\
$\mathrm{k}_{3}$ (Ramindo 1) & & & \\
\hline Konsentrasi asam giberelat $(\mathrm{G})$ & $1,06 \mathrm{a}$ & $0,72 \mathrm{a}$ & $1,78 \mathrm{a}$ \\
$\mathrm{g}_{1}(0$ ppm) & $1,00 \mathrm{a}$ & $0,94 \mathrm{ab}$ & $1,39 \mathrm{a}$ \\
$\mathrm{g}_{2}(75 \mathrm{ppm})$ & $1,39 \mathrm{a}$ & $1,44 \mathrm{bc}$ & $2,89 \mathrm{a}$ \\
$\mathrm{g}_{3}(150 \mathrm{ppm})$ & $1,72 \mathrm{a}$ & $2,61 \mathrm{c}$ & $2,89 \mathrm{a}$ \\
$\mathrm{g}_{4}(225 \mathrm{ppm})$ & &
\end{tabular}

Keterangan: Nilai rata-rata perlakuan yang ditandai dengan huruf yang sama tidak berbeda nyata menurut Uji Lanjut Jarak Berganda Duncan pada taraf nyata 5\%. 
$\mathrm{GA}_{3}$ memengaruhi terjadinya sintesis protein yang berkaitan erat dengan pembentukan klorofil dan akan memengaruhi terjadinya fotosintesis pada tanaman. Fotosintesis yang terjadi pada tanaman akan memengaruhi jumlah fotosintat yang terdapat pada tanaman berupa gula atau glukosa. Karbohidrat ini juga banyak terdapat pada rhizoma dimana rhizoma ini merupakan faktor utama yang mempengaruhi perkembangan tunas (Mudyantini, 2008).

Pertambahan jumlah daun. Pengaruh interaksi klon dan $\mathrm{GA}_{3}$ terhadap pertambahan jumlah daun terjadi pada tanaman rami umur 12 MST, sedangkan pengaruh mandiri hanya terjadi pada $\mathrm{GA}_{3}$ umur 10 MST (Tabel 2).

Tabel 2. Pengaruh Mandiri Klon Rami atau Konsentrasi Asam Giberelat terhadap Pertambahan Jumlah Daun

\begin{tabular}{|c|c|c|}
\hline \multirow[t]{2}{*}{ Perlakuan } & \multicolumn{2}{|c|}{$\begin{array}{l}\text { Pertambahan Jumlah Daun } \\
\text { (helai) }\end{array}$} \\
\hline & $8 \mathrm{MST}$ & $10 \mathrm{MST}$ \\
\hline \multicolumn{3}{|l|}{ Klon (K) } \\
\hline $\mathrm{k}_{1}$ (Pujon 13) & 34,21 a & 31,96 a \\
\hline $\mathrm{k}_{2}$ (Bandung A) & 25,75 a & 24,08 a \\
\hline $\mathrm{k}_{3}($ Ramindo 1$)$ & 23,75 a & 26,29 a \\
\hline \multicolumn{3}{|l|}{$\begin{array}{l}\text { Konsentrasi asam } \\
\text { giberelat }(G)\end{array}$} \\
\hline $\mathrm{g}_{1}(0 \mathrm{ppm})$ & 19,83 a & $22,89 \mathrm{ab}$ \\
\hline $\mathrm{g}_{2}(75 \mathrm{ppm})$ & 24,83 a & $27,72 \mathrm{ab}$ \\
\hline $\mathrm{g}_{3}(150 \mathrm{ppm})$ & 30,11 a & $18,94 a$ \\
\hline $\mathrm{g}_{4}(225 \mathrm{ppm})$ & 36,83 a & $40,22 b$ \\
\hline
\end{tabular}

Keterangan: Nilai rata-rata perlakuan yang ditandai dengan huruf yang sama tidak berbeda nyata menurut Uji Lanjut Jarak Berganda Duncan pada taraf nyata $5 \%$.

Pertambahan jumlah daun ke tiga klon belum terterlihat berbeda nyata pada umur 8 dan 10 tahun, tapi berbeda pada 12 MST, hal ini menunjukkan bahwa pada awal-awal pertumbuhan jumah daun masih belum terlihat berbeda, baru pada 12 MST terlihat berbeda.

Pada 10 MST jumlah daun yang diberi $\mathrm{GA}_{3}$ 225 lebih banyak dibandingkan dengan konsentrasi 150 ppm. Giberelin diketahui dapat memengaruhi pertumbuhan tanaman termasuk di dalamnya jumlah daun dan perkembangan daun muda (Salisbury dan Ross, 1995). Pertambahan jumlah daun pada tanaman ini juga dapat terjadi karena adanya pengaruh dari genetik dalam klon tersebut dimana pengaruh genetik tersebut akan memengaruhi hasil yang didapat. Pengaruh interaksi klon dan $\mathrm{GA}_{3}$ pada parameter jumlah daun umur 12 MST dapat dilihat pada Tabel 3.
Tabel 3. Pengaruh Interaksi Klon dan Konsentrasi Asam Giberelat terhadap Pertambahan Jumlah Daun (helai) umur 12 MST.

\begin{tabular}{ccccc}
\hline & \multicolumn{4}{c}{ Asam giberelat (g) } \\
\cline { 2 - 5 } Klon (k) & $\mathrm{g}_{1}(0$ & $\mathrm{g}_{2}(75$ & $\mathrm{g}_{3}(150$ & $\mathrm{g}_{4}(225$ \\
& $\mathrm{ppm})$ & $\mathrm{ppm})$ & $\mathrm{ppm})$ & $\mathrm{ppm})$ \\
\hline \multirow{2}{*}{$\mathrm{k}_{1}$ (Pujon 13) } & $16,17 \mathrm{a}$ & $47,00 \mathrm{~b}$ & $32,83 \mathrm{a}$ & $9,83 \mathrm{a}$ \\
& $\mathrm{AB}$ & $\mathrm{B}$ & $\mathrm{AB}$ & $\mathrm{A}$ \\
$\mathrm{k}_{2}$ (Bandung A) & $9,83 \mathrm{a}$ & $24,33 \mathrm{a}$ & $27,50 \mathrm{a}$ & $46,50 \mathrm{~b}$ \\
& $\mathrm{~A}$ & $\mathrm{AB}$ & $\mathrm{AB}$ & $\mathrm{B}$ \\
$\mathrm{k}_{3}$ (Ramindo 1) & $19,17 \mathrm{a}$ & 27,17 a & $94,67 \mathrm{~b}$ & $34,00 \mathrm{~b}$ \\
& $\mathrm{~A}$ & $\mathrm{~A}$ & $\mathrm{~B}$ & $\mathrm{~A}$ \\
\hline
\end{tabular}

Keterangan: Angka yang diikuti huruf yang sama tidak berbeda nyata menurut uji lanjut jarak berganda Duncan pada taraf nyata 5\%. Huruf kapital dibaca arah horizontal (baris) dan huruf kecil dibaca arah vertikal (kolom).

Tabel 3 menunjukkan bahwa pada klon Pujon 13 jumlah daun yang diberi 75 ppm $\mathrm{GA}_{3}$ lebih banyak dibandingkan dengan yang diberi $225 \mathrm{ppm}$ tapi tidak berbeda dengan 0 ppm dan 150 ppm. Padaklon Bandung A, jumlah daun pada 225 ppm lebih banyak dibandingkan dengan tanpa $\mathrm{GA}_{3}$ tetapi tidak berbeda dengan perlakuan 150 ppm dan 75 ppm. Padaklon Ramindo 1jumlah daun terbanyak dihasilkan oleh perlakuan asam giberelat $150 \mathrm{ppm}$. Perlakuan asam giberelat yang diaplikasikan pada tanaman rami akan memengaruhi pertambahan jumlah daun pada tanaman. Interaksi dari asam giberelat dan klon dipengaruhi oleh faktor genetik dari klon tersebut. Hal tersebut terjadi karena asam giberelat memengaruhi pertumbuhan tanaman termasuk ukuran dan jumlah daun serta perkembangan daun muda dibandingkan dengan yang tidak diberikan perlakuan asam giberelat (Salisbury dan Ross, 1995).

Pertambahan diameter batang. Pertambahan diameter batang pada umur 8 MST dan 12 MST dipengaruhi oleh interaksi klon dan $\mathrm{GA}_{3}$, tetapi pada 10 MST tidak terdapat pengaruh interaksi maupun pengaruh mandiri klon dan GA3 terhadap diameter batang (Tabel 4).

Perlakuan klon Pujon 13 dan asam giberelat 150 ppm cenderung berpotensi menunjukkan pengaruh mandiri paling baik dibandingkan taraf lain terhadap pertambahan diameter batang. Pemberian $\mathrm{GA}_{3}$ diduga dapat memengaruhi pemanjangan dan pembesaran sel, sehingga dengan adanya penambahan $\mathrm{GA}_{3}$ pada tanaman rami, dapat memperbesar diameter batang tanaman rami, yang juga dipengaruhi oleh faktor genetik dari tanaman itu sendiri. 
Tabel 4. Pengaruh Mandiri Klon Rami atau Konsentrasi Asam Giberelat terhadap Pertambahan Diameter Batang

\begin{tabular}{lc}
\hline \multirow{2}{*}{$\quad$ Perlakuan } & $\begin{array}{c}\text { Pertambahan Diameter Batang } \\
(\mathrm{cm})\end{array}$ \\
\cline { 2 - 2 } & $10 \mathrm{MST}$ \\
\hline Klon (K) & $0,15 \mathrm{a}$ \\
$\mathrm{k}_{1}$ (Pujon 13) & $0,08 \mathrm{a}$ \\
$\mathrm{k}_{2}$ (Bandung $\left.\mathrm{A}\right)$ & $0,11 \mathrm{a}$ \\
$\mathrm{k}_{3}$ (Ramindo 1$)$ & \\
\hline Konsentrasi asam & \\
giberelat $(\mathrm{G})$ & $0,11 \mathrm{a}$ \\
$\mathrm{g}_{1}(0$ ppm $)$ & $0,10 \mathrm{a}$ \\
$\mathrm{g}_{2}(75$ ppm) & $0,15 \mathrm{a}$ \\
$\mathrm{g}_{3}(150 \mathrm{ppm})$ & $0,10 \mathrm{a}$ \\
$\mathrm{g}_{4}(225 \mathrm{ppm})$ &
\end{tabular}

Keterangan: Nilai rata-rata perlakuan yang ditandai dengan huruf yang sama tidak berbeda nyata menurut Uji Lanjut Jarak Berganda Duncan pada taraf nyata $5 \%$.

Pengaruh interaksi antara klon dan asam giberelat terhadap pertambaan diameter batang pada 8 MST dan 12 MST dapat dilihat pada Tabel 5 dan 6. Pada Tabel 5, perlakuan klon Pujon 13 menunjukkan pengaruh interaksi terbaik dengan asam giberelat 150 ppmterhadap diameter batang tetapi tidak berbeda dengan perlakuan $0 \mathrm{ppm}$ dan 75 ppm, perlakuan klon Bandung A berpengaruh terbaik dengan perlakuan asam giberelat $225 \mathrm{ppm}$ dan tidak berbeda dengan $150 \mathrm{ppm}$, perlakuan klon Ramindo 1 tidak terlihat adanya perbedaan diameter batang pada seluruh perlakuan asam giberelat.

Tabel 6 menunjukkan bahwa klon Pujon 13 dan Bandung A berinteraksi terhadap berbagai konsentrasi asam giberelat yang berbeda dibandingkan dengan perlakuan kontrol. Klon Ramindo 1 tidak menunjukkan adanya pengaruh pada berbagai taraf $\mathrm{GA}_{3}$. Klon Pujon 13 berinteraksi terbaik terhadap konsentrasi asam giberelat 75 ppm. Klon Bandung A berinteraksi dengan perbedaan terbaik pada konsentrasi asam giberelat 225 ppm dan tidak berbeda nyata dengan 150 ppm. Hasil analisis pada tabel menunjukkan bahwa setiap perlakuan $g$ terhadap klon yang berbeda memberikan hasil yang berbeda pula pada umur 12 MST. Pengaruh pertambahan diameter batang dapat terjadi karena $\mathrm{GA}_{3}$ menyebabkan pembelahan dan pembesaran sel (Gardner dkk., 1991). Konsentrasi $\mathrm{GA}_{3}$ yang lebih tinggi juga menyebabkan pembentukan floem yang lebih banyak dan mengakibatkan pertambahan diameter batang. Pertambahan diameter batang juga dipengaruhi aktivitas kambium dalam menghasilkan xilem dan floem (Fahn,1995).

Tabel 5. Pengaruh Interaksi Klon dan Asam Giberelat terhadap Pertambahan Diameter Batang $(\mathrm{cm})$ umur 8 MST

\begin{tabular}{ccccc}
\hline & \multicolumn{4}{c}{ Asam giberelat (g) } \\
\cline { 2 - 5 } Klon (k) & $\mathrm{g}_{1}(0$ & $\mathrm{g}_{2}(75$ & $\mathrm{g}_{3}(150$ & $\mathrm{g}_{4}(225$ \\
& $\mathrm{ppm})$ & $\mathrm{ppm})$ & $\mathrm{ppm})$ & $\mathrm{ppm})$ \\
\hline \multirow{2}{*}{$\mathrm{k}_{1}$ (Pujon 13) } & $0,10 \mathrm{a}$ & $0,09 \mathrm{a}$ & $0,13 \mathrm{a}$ & $0,08 \mathrm{a}$ \\
& $\mathrm{AB}$ & $\mathrm{AB}$ & $\mathrm{B}$ & $\mathrm{A}$ \\
$\mathrm{k}_{2}$ (Bandung A) & $0,11 \mathrm{a}$ & $0,11 \mathrm{ab}$ & $0,17 \mathrm{~b}$ & $0,25 \mathrm{~b}$ \\
& $\mathrm{~A}$ & $\mathrm{~A}$ & $\mathrm{AB}$ & $\mathrm{B}$ \\
$\mathrm{k}_{3}$ Ramindo 1) & $0,16 \mathrm{a}$ & $0,18 \mathrm{~b}$ & $0,18 \mathrm{~b}$ & $0,15 \mathrm{ab}$ \\
& $\mathrm{A}$ & $\mathrm{A}$ & $\mathrm{A}$ & $\mathrm{A}$ \\
\hline
\end{tabular}

Keterangan: Angka yang diikuti huruf yang sama tidak berbeda nyata menurut uji lanjut jarak berganda Duncan pada taraf nyata 5\%. Huruf kapital dibaca arah horizontal (baris) dan huruf kecil dibaca arah vertikal (kolom).

Tabel 6. Pengaruh Interaksi Klon dan Asam Giberelat terhadap Pertambahan Diameter Batang (cm) umur 12 MST.

\begin{tabular}{ccccc}
\hline & \multicolumn{4}{c}{ Asam giberelat $(\mathrm{g})$} \\
\cline { 2 - 5 } Klon (k) & $\mathrm{g}_{1}(0$ & $\mathrm{g}_{2}(75$ & $\mathrm{g}_{3}(150$ & $\mathrm{g}_{4}(225$ \\
& $\mathrm{ppm})$ & $\mathrm{ppm})$ & $\mathrm{ppm})$ & $\mathrm{ppm})$ \\
\hline $\mathrm{k}_{1}$ (Pujon 13) & $0,07 \mathrm{a}$ & $0,14 \mathrm{a}$ & $0,07 \mathrm{a}$ & $0,06 \mathrm{a}$ \\
& $\mathrm{A}$ & $\mathrm{B}$ & $\mathrm{A}$ & $\mathrm{A}$ \\
$\mathrm{k}_{2}$ (Bandung A) & $0,07 \mathrm{ab}$ & $0,11 \mathrm{a}$ & $0,16 \mathrm{~b}$ & $0,25 \mathrm{~b}$ \\
& $\mathrm{~A}$ & $\mathrm{~A}$ & $\mathrm{AB}$ & $\mathrm{B}$ \\
$\mathrm{k}_{3}$ (Ramindo 1) & $0,09 \mathrm{~b}$ & $0,09 \mathrm{a}$ & $0,10 \mathrm{ab}$ & $0,10 \mathrm{a}$ \\
& $\mathrm{A}$ & $\mathrm{A}$ & $\mathrm{A}$ & $\mathrm{A}$
\end{tabular}

Keterangan: Angka yang diikuti huruf yang sama tidak berbeda nyata menurut uji lanjut jarak berganda Duncan pada taraf nyata 5\%. Huruf kapital dibaca arah horizontal (baris) dan huruf kecil dibaca arah vertikal (kolom).

Bobot segar. Besarnya kandungan air selain bahan organik dalam jaringan atau organ tumbuh dapat ditunjukkan dengan menghitung bobot segar (Sitompul dan Guritno, 1995 dalam Mudyantini, 2008). Selain air, kadar dari bobot segar juga dipengaruhi oleh unsur hara dan bahan organik yang terkandung dalam suatu tanaman.

Tabel 7menunjukkan bahwa masingmasing perlakuan berpengaruh mandiri pada parameter bobot segar daun. Pada parameter bobot segar batang, hanya perlakuan klon yang menunjukkan adanya pengaruh mandiri, sedangkan perlakuan konsentrasi asam giberelat tidak menunjukkan adanya pengaruh.

Pengaruh pada faktor klon ditunjukkan bahwa klon Bandung A dan Ramindo 1 
memiliki bobot segar daun yang lebih baik dibandingkan dengan klon Pujon 13. Perlakuan klon Pujon 13 merupakan klon dengan produktivitas yang paling sedikit dibandingkan dengan klon lainnya yaitu hanya sebesar 1,9-2,5 ton/ ha/tahun. Klon Ramindo 1 memiliki produktivitas sebesar 2-2,7 ton/ha/tahun, dan klon Bandung A memiliki produktivitas sebesar $2-2,6$ ton/ha/tahun.

Tabel 7. Pengaruh Mandiri Klon dan Konsentrasi Asam Giberelat terhadap Bobot segar Tanaman.

\begin{tabular}{|c|c|c|}
\hline \multirow{2}{*}{ Perlakuan } & \multicolumn{2}{|c|}{ Bobot segar (g) } \\
\hline & Batang & Daun \\
\hline \multicolumn{3}{|l|}{$\overline{\text { Klon }(\mathrm{K})}$} \\
\hline $\mathrm{k}_{1}$ (Pujon 13) & 68,65 a & 58,58 a \\
\hline $\mathrm{k}_{2}$ (Bandung A) & $114,54 \mathrm{~b}$ & $95,42 \mathrm{~b}$ \\
\hline $\mathrm{k}_{3}$ (Ramindo 1$)$ & $132,73 \mathrm{~b}$ & $95,33 \mathrm{~b}$ \\
\hline \multicolumn{3}{|c|}{ Konsentrasi asam giberelat $(\mathrm{G})$} \\
\hline $\mathrm{g}_{1}(0 \mathrm{ppm})$ & 116,38 a & 72,83 a \\
\hline $\mathrm{g}_{2}(75 \mathrm{ppm})$ & 105,82 a & 73,88 a \\
\hline $\mathrm{g}_{3}(150 \mathrm{ppm})$ & 70,71 a & $65,77 \mathrm{a}$ \\
\hline $\mathrm{g}_{4}(225 \mathrm{ppm})$ & $128,31 \mathrm{a}$ & $119,97 \mathrm{~b}$ \\
\hline
\end{tabular}

Keterangan: Nilai rata-rata perlakuan yang ditandai dengan huruf yang sama tidak berbeda nyata menurut Uji Lanjut Jarak Berganda Duncan pada taraf nyata $5 \%$.

Faktor kedua yang memengaruhi bobot segar daun yaitu faktor konsentrasi asam giberelat menunjukkan bahwa taraf asam giberelat $225 \mathrm{ppm}$ merupakan taraf yang paling baik dibandingkan dengan taraf 0 ppm, 75 ppm, dan $150 \mathrm{ppm}$ sehingga bobot segar daun lebih berat pada 225 ppm. Giberelin akan memengaruhi ukuran sel tanaman, menjadi lebih panjang dan mengakibatkan sel mudah untuk membesar. Pertambahan ukuran pada tanaman akan diakibatkan terjadinya peningkatan jumlah sel tanaman. Jumlah sel yang meningkat ini akan memengaruhi peningkatan fotosintesis, meningkatkan karbohidrat, dan juga meningkatkan bobot tanaman (Salisbury dan Ross, 1995).

Pertambahan tinggi tanaman. Hasil analisis menunjukkan terjadi interaksi antara klon dan $\mathrm{GA}_{3}$ terhadap pertambahan tinggi tanaman rami hanya pada umur 12 MST. Pertambahan tinggi rami umur 8 MST, dan 10 MST tidak dipengaruh oleh klon dan konsentrasi $\mathrm{GA}_{3}$. Pengaruh mandiri klon dan asam giberelat terhadap tinggi tanaman dapat dilihat pada Tabel 8.

Tabel 8 memperlihatkan bahwa pada umur rami 8 MST, dan 10 MST kedua perlakuan baik perlakuan klon maupun asam giberelat tidak menunjukkan adanya pengaruh secara mandiri. Ramindo 1 cenderung berpotensi sebagai perlakuan yang lebih baik dibandingkan perlakuan kedua klon lainnya pada 8 MST, sedangkan pada 10 MST, yang cenderung terbaik yaitu Bandung A. Menurut deskripsi klon Ramindo 1 merupakan klon dengan tinggi tanaman terbesar dibandingkan dengan kedua klon lainnya.

Tabel 8. Pengaruh Mandiri Klon Rami atau Konsentrasi Asam Giberelat terhadap Pertambahan Tinggi Tanaman.

\begin{tabular}{|c|c|c|}
\hline \multicolumn{3}{|c|}{$\begin{array}{c}\text { Pertambahan } \\
\text { Tinggi }(\mathrm{cm})\end{array}$} \\
\hline & $8 \mathrm{MST}$ & $10 \mathrm{MST}$ \\
\hline \multicolumn{3}{|l|}{ Klon (K) } \\
\hline $\mathrm{k}_{1}$ (Pujon 13) & 16,64 a & 14,43 a \\
\hline $\mathrm{k}_{2}$ (Bandung A) & 32,41 a & 18,29 a \\
\hline $\mathrm{k}_{3}$ (Ramindo 1$)$ & 43,85 a & 17,94 a \\
\hline \multicolumn{3}{|c|}{ Konsentrasi asam giberelat (G) } \\
\hline $\mathrm{g}_{1}(0 \mathrm{ppm})$ & 29,47 a & 19,59 a \\
\hline $\mathrm{g}_{2}(75 \mathrm{ppm})$ & 28,69 a & 18,62 a \\
\hline $\mathrm{g}_{3}(150 \mathrm{ppm})$ & 33,80 a & 16,26 a \\
\hline $\mathrm{g}_{4}(225 \mathrm{ppm})$ & 45,25 a & 13,06 a \\
\hline
\end{tabular}

Keterangan: Nilai rata-rata perlakuan yang ditandai dengan huruf yang sama tidak berbeda nyata menurut Uji Lanjut Jarak Berganda Duncan pada taraf nyata $5 \%$. Nilai rata-rata perlakuan yang tidak diberi notasi huruf menandakan perlakuan tidak berpengaruh nyata terhadap respon berdasarkan analisis ragam taraf nyata $5 \%$.

Pada 8 MST perlakuan asam giberelat 225 ppm cenderung lebih tinggi dibandingkan perlakuan $\mathrm{GA}_{3}$ yang lainnya, sedangkan pada 10 MST, perlakuan 0 ppm cenderung lebih tinggi. Hal itu terjadi karena $\mathrm{GA}_{3}$ dapat memengaruhi pembelahan dan pembesaran sel tanaman sehingga perlakuan $\mathrm{GA}_{3} 225 \mathrm{ppm}$ dapat memberikan hasil pertambahan tinggi yang cenderung paling besar.

Pengaruh interaksi antara klon dan $\mathrm{GA}_{3}$ terhadap pertambahan tinggi tanaman rami pada umur 12 MS dapat dilihat padaTabel 9.

Tanaman rami klon Pujon 13 yang diberi $\mathrm{GA}_{3} 225$ ppm merupakan klon dengan pertambahan tinggi tanaman terbesar. Pertambahan tinggi tanaman berhubungan dengan peranan giberelin bagi tanaman dimana giberelin ini dapat meningkatkan kandungan auksin endogen dalam tanaman, dan memengaruhi tinggi tanaman (Depari, 2013). Pertumbuhan dan proses diferensiasi dari tanaman dipengaruhi oleh hormon endogen dalam tanaman dan zat 
atau hormon sintetik yang dipalikasikan kepada tanaman akan bereaksi dengan hormon endogen dalam tanaman tersebut (Lakitan, 1995).

Tabel 9. Pengaruh Interaksi Klon dan Asam Giberelat terhadap Pertambahan Tinggi Tanaman (cm) umur 12 MST

\begin{tabular}{ccccc}
\hline \multirow{2}{*}{ Klon (k) } & \multicolumn{4}{c}{ Asam giberelat $(\mathrm{g})$} \\
\cline { 2 - 5 } & $\mathrm{g}_{1}(0$ & $\mathrm{g}_{2}(75$ & $\mathrm{g}_{3}(150$ & $\mathrm{g}_{4}(225$ \\
$\mathrm{ppm})$ & $\mathrm{ppm})$ & $\mathrm{ppm})$ & $\mathrm{ppm})$ \\
\hline $\mathrm{k}_{1}$ (Pujon 13) & $9,00 \mathrm{a}$ & $11,75 \mathrm{a}$ & $16,12 \mathrm{a}$ & $25,23 \mathrm{~b}$ \\
& $\mathrm{~A}$ & $\mathrm{~A}$ & $\mathrm{~A}$ & $\mathrm{~B}$ \\
$\mathrm{k}_{2}$ (Bandung A) & $24,58 \mathrm{a}$ & $23,33 \mathrm{a}$ & $18,13 \mathrm{a}$ & 15,70 \\
& $\mathrm{~A}$ & $\mathrm{~A}$ & $\mathrm{~A}$ & $\mathrm{Ab}$ \\
$\mathrm{k}_{3}$ (Ramindo 1) & 16,57 a & 21,00 a & 18,00 a & $9,00 \mathrm{a}$ \\
& $\mathrm{B}$ & $\mathrm{B}$ & $\mathrm{B}$ & $\mathrm{A}$ \\
\hline
\end{tabular}

Keterangan: Angka yang diikuti huruf yang sama tidak berbeda nyata menurut uji lanjut jarak berganda Duncan pada taraf nyata $5 \%$. Huruf kapital dibaca arah horizontal (baris) dan huruf kecil dibaca arah vertikal (kolom).

\section{Kesimpulan dan Saran}

Berdasarkan atas hasil analisis data dan pembahasan, maka dapat ditarik kesimpulan sebagai berikut:

1. Terdapat pengaruh interaksi klon dengan konsentrasi $\mathrm{GA}_{3}$ terhadap jumlah daun umur 12 MST, diameter batang umur 8 dan 12 MST, dan tinggi tanaman 12 MST.

2. Pengaruh interaksi terbaik terjadi pada perlakuan klon Bandung A dengan asam giberelat 225 ppm, ditunjukkan oleh jumlah daun umur 12 MST, serta diameter batang umur 8 dan 12 MST. Pengaruh mandiri terbaik juga dihasilkan oleh klon Bandung Asertaasam giberelat $225 \mathrm{ppm}$.

Saran. Sebaiknya dilakukan pengujian terhadap kualitas serat rami melalui proses dekortikasi untuk melihat pengaruh dari giberelin bagi kualitas serat rami.

\section{Daftar Pustaka}

Budiarto, K. Dan Wuryaningsih. 2007. Respon Pembungaan Beberapa Kultivar Anthurium Bunga Potong. Jurnal Agritop No.2 Vol 26. Hal 51-56.

Depari, S. O. S. 2013. Pengaruh konsentrasi GA3 terhadap pertumbuhan dan produksi tiga varietas mentimun (Cucumis sativus L.). Vol. III No. 01. Jurnal Stevia. Hal 5-13.

Fahn, A. 1995. Anatomi Tumbuhan. Penerjemah: Soediarto, A. Yogyakarta: Universitas Gadjah Mada Press.

Gardner, F.P., R.B. Pearcce, dan R.I. Mitchell. 1991. Fisiologi Tanaman Budidaya. Penerjemah: Susilo,H. Jakarta: UI Press.

Lakitan, B. 1995. Dasar-dasar Fisiologi Tumbuhan. PR Raja Grafindo Persada. Jakarta.

Mudyantini, W. 2008. Pertumbuhan, kandungan selulosa, dan lignin pada rami (Boehmeria nivea L. Gaudich) dengan pemberian asam giberelat $\left(\mathrm{GA}_{3}\right)$. Jurnal Biodiversitas Vol 9, No. 4 hal 269-274.

Musaddad, M. A. 2007. Agribisnis Tanaman Rami. Depok: Penebar Swadaya. 82 hal.

Purwati, R. D. 2010. Strategi pengembangan rami (Boehmeria nivea Gaud). Jurnal perspektif Vol. 9 No. 2 Hlm 106 - 118.

Salisbury, F. B. Dan C. W. Ross. 1995. Fisiologi Tumbuhan, Biokimia Tumbuhan. Jilid 2. Penerjemah: Lukman, D. R. dan Sumaryono. Bandung: ITB.

Suherman, C., A. Nuraini, A.P. Wulandari, M. Kadapi. 2017. Enhancing the growth and yield of ramie (Boehmeria nivea L.) by ramie biomass waste in liquid form and gibberellic acid. IOP Journal Vol 65, No.1. Hal 1-5.

Syafi'i,M. 2005. Pengaruh konsentrasi dan waktu pemberian gibberellin $\left(\mathrm{GA}_{3}\right)$ terhadap pertumbuhan dan hasil tanaman melon (Cucumis melo L.) dengan sistem tanam hidroponik irigasi tetes. Fakultas Pertanian, Universitas Sebelas Maret Surakarta.

Trisiana, L.S, T. Maideliza, R. Mayerni. 2016. Kualitas serat lima klon tanaman rami (Boehmeria nivea L. GAUD). Jurnal EKSAKTA Vol 1 Tahun XVII, Februari 2016. Hal 8-16 